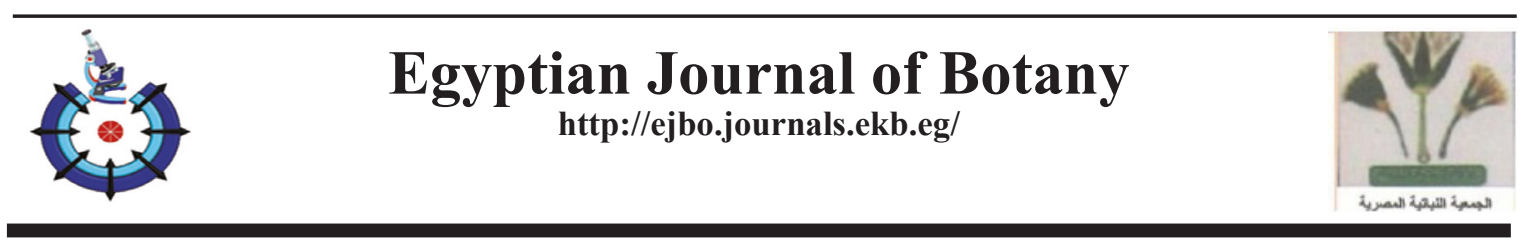

\title{
Elicitors Enhancing Phenolics Content and Related Gene Expression Variation in Petal - Derived Calli of Rosa damascena Mill.
}

\author{
Hadeer Y. Darwish ${ }^{(1)}$, Shawkat M. Ahmed ${ }^{(2) \#}$ \\ ${ }^{(1)}$ Medicinal and Aromatic Plants Department, Horticulture Institute, Agricultural \\ Research Center, Giza, Egypt; (2)Biology Department, Faculty of Education, Ain \\ Shams University, Cairo, Egypt.
}

\begin{abstract}
D UE to increasing importance of roses in producing secondary products including essential oils and pharmaceutical compounds as phenolics, several protocols were developed from different explants of roses. For that purpose, an efficient callus initiation procedure for Rosa damascena Mill. cultivated in Taif, KSA was developed by using petal explant cultures supplemented with nine elicitors for improving phenolics content. As well, related genetic expression variation of the elicited calli was studied by biochemical (protein and isozyme) analyses. Except for rose and geranium oils, seven elicitors increased the phenolics content in $R$. damascena calli compared with the control. High qualitative differences were observed in their banding patterns reflecting biochemical aberrations in treated calli. A dendrogram, based on UPGMA method of cluster analysis, upheld the notable fluctuations in phenolics content and gene expression occurred by different elicitors.
\end{abstract}

Keywords: Calli, Elicitation, Genetic expression, Isozyme, Phenolics, Rosa damascena.

\section{Introduction}

Plant tissue culture has been proposed as an alternative to conventional agriculture for the production of secondary metabolites due to the possibility of controlling the quality and quantity of the compound of interest by controlling the factors affecting its synthesis and/or accumulation (Rodriguez-Sahagun et al., 2012). In the ornamental plants, rose is one of the most economically important species and one of the top five ornamental plants worldwide. Out of 200 species of the genus Rosa, the $R$. damascena is the important essential oil bearing plant (Pal \& Singh, 2013). Rose callus cultures have been utilized to investigate physiological events and to produce secondary products that are known to play a major role in the adaptation of plants to their environment and also represent an important source of pharmaceuticals (Rao \& Ravishankar, 2002). The physiological functions of Rosaceae may be partly attributed to their abundance of phenolics that possess a wide spectrum of biochemical activities, such as anti-inflammatory (Crespo et al., 1999), antimutagenic (Miyazawa et al., 2000) and anticancer (Ren et al., 2003). There is an effort to improve the secondary contents of the plants through tissue culture and elicitation techniques. Elicitation is the process of adding an abiotic and/or biotic elicitor to induce and enhance the formation of secondary metabolites that have been normally do not accumulate in plants (Kiong et al., 2005; Karuppusamy, 2009). The process has been established in several plant species such as Silybum marianum (SanchezSampedro et al., 2005), Vitis vinifera ( Mihai et al., 2009), Zingiber officinale (El-Nabarawy et al., 2015).

On the other hand, higher plant cells cultured in vitro showed a genetic instability that was also characteristic of initiated callus cells. The first

"Corresponding author email: shamahmoh@gmail.com

Received 22/12/2018; Accepted 17/7/2019

DOI: $10.21608 /$ ejbo.2019.6799.1271

Edited by: Prof. Dr. Soliman Haroun, Faculty of Science, Kafr El-Sheikh University, Kafr El-Sheikh, Egypt.

C2020 National Information and Documentation Center (NIDOC) 
observation of somaclonal variation was reported by Braun (1959). The variability existing in plant tissue and cell cultures received much attention and neologisms were proposed to refer to the results of in vitro cultures of plants (Larkin \& Scowcroft, 1981). In this regard, proteins and isozymes have been used widely as markers for characterizing variation and assessment of genetic fidelity in many plants (Thevenot et al., 1992; Jayasree et al., 1998; Medina et al., 2004; Ivanova et al., 2013) through organogenesis and somatic embryogenesis.

In spite of $R$. damascena is a rich source of phenolic compounds, few data exist regarding enhancement of phenolics content and biochemical analyses in callus of $R$. damascena. Therefore, the present work aims to initiate calli from in vitro petal explants of $R$. damascena L. under elicitation of nine abiotic and biotic elicitors for improving phenolics content and verify the related genetic expression variation using protein and isozyme analyses.

\section{Materials and Methods}

\section{Source of explant}

Petals were excised from vigorously flowering shoots of $R$. damascena plants cultivated in Taif governorate, KSA and used as the explant sources cultured on medium containing kinetin (Kin) at $0.1 \mathrm{mg} / \mathrm{L}$ and 1-naphthaleneacetic acid (NAA) at $1.0 \mathrm{mg} / \mathrm{L}$.

\section{Culture media}

Explants were cultured on Murashige \& Skoog (1962) (MS) medium. The medium of $R$. damascena was supplemented with nine abiotic and biotic elicitors, i.e. glycine, casein hydrolysate, yeast extract, L-ascorbic acid, citric acid and thiamine at rate of $0.5 \mathrm{~g} / \mathrm{L}$, whereas, jasmine oil, rose oil and geranium oil at $0.8 \mathrm{~g} / \mathrm{L}$. Oils of rose and geranium were obtained by distillation using water vapor device, whereas jasmine oil was purchased as a pure oil from market. Each treatment included six jars in every three explants. Agar was used at $7 \mathrm{~g} / \mathrm{l}$ and sucrose at $30 \mathrm{~g} / \mathrm{L}$.

\section{Experiment condition}

The media was adjusted to $\mathrm{pH}(5.7-5.8)$ by adding suitable amount of $0.1 \mathrm{~N} \mathrm{HCl}$ or $0.1 \mathrm{~N}$ $\mathrm{NaOH}$ using the $\mathrm{pH}$ meter before autoclaving. The media were distributed into clean jars $(50 \mathrm{ml})$.
Each of which contained $30 \mathrm{ml}$ of nutrient media. Afterwards, jars were autoclaved for $15 \mathrm{~min}$. at $121^{\circ} \mathrm{C}, 1.5 \mathrm{~kg} / \mathrm{cm}^{3}$. All treatments were incubated in the growth chamber at $26 \pm 2^{\circ} \mathrm{C}$ and exposed to $16 \mathrm{hrs}$. light/day photoperiod under constant fluorescent light of 1500 Lux.

\section{Total phenolics content}

Total phenolics were determined using Folin-Ciocalteau reagents (Singleton \& Rossi, 1965). Gallic acid standard solution $(2.0 \mathrm{mg} /$ $\mathrm{ml}$ ) was prepared by accurately weighing $0.01 \mathrm{~g}$ and dissolving in $50 \mathrm{ml}$ of distilled water. After standing $60 \mathrm{~min}$ at room temperature, absorbance was measured spectrophotometrically at $765 \mathrm{~nm}$. Results were expressed as $\mu \mathrm{g} / \mathrm{g}$ gallic acid equivalents (GAE).

\section{Protein analysis}

To extract proteins, $1 \mathrm{~g}$ of each elicited callus was blended with $1 \mathrm{M}$ Tris- $\mathrm{HCl}$ buffer, $\mathrm{pH} 8.8$ using a mortar and pestle. The homogenates were transferred into clean Eppendorf tubes and centrifuged at $10.000 \mathrm{rpm}$ for $10 \mathrm{~min}$. The supernatants (protein extract) were transferred to new tubes and kept in deep-freeze until use. For electrophoresis, $10 \mu 1$ of the extract were mixed with $10 \mu 1$ of a treatment buffer. Electrophoresis was carried out by the modified discontinuous sodium dodecyl sulphate- polyacrylamide gel electrophoresis (DISC SDS-PAGE) method (Laemmli, 1970) using 12\% (w/v) acrylamide separating gel $(0.375 \mathrm{M}$ Tris- $\mathrm{HCl}$ buffer, $\mathrm{pH}$ $8.8)$ and $4 \%(\mathrm{w} / \mathrm{v})$ acrylamide stacking gel (0.125M Tris-HCl, pH 6.8). The electrode buffer was Tris-glycine $(2.25 \mathrm{~g}$ Tris and $10.8 \mathrm{~g}$ glycine per $750 \mathrm{ml}$ buffer solution, $\mathrm{pH} 8.3$ ) with $0.1 \%(\mathrm{w} / \mathrm{v})$ SDS. Gels were stained overnight in $0.1 \%(\mathrm{w} / \mathrm{v})$ Coomassie Brilliant Blue-R250 solution containing 40\% (v/v) methanol and $10 \%(\mathrm{v} / \mathrm{v})$ trichloracetic acid, then destained and photographed.

\section{Isozyme analysis}

The examined isozymes were: $\alpha$-and $\beta$-esterases (EST); (E.C.3.1.1.1), malate dehydrogenase (MDH); (E.C.1.1.1.37) and peroxidase (PRX); (E.C.1.11.1.7). For their extraction, $1 \mathrm{~g}$ of the elicited callus was homogenized in $1 \mathrm{ml}$ extraction buffer (1M Tris$\mathrm{HCl}, \mathrm{pH} 8.8$ ) using a mortar and pestle, centrifuged at $10.000 \mathrm{rpm}$ for $5 \mathrm{~min}$, the supernatant was kept at $-20^{\circ} \mathrm{C}$ until use. For isozymes separation, $10 \%$ $(\mathrm{w} / \mathrm{v})$ native-polyacrylamide gel electrophoresis 
method was used (Stegemann et al., 1987). For electrophoresis, $50 \mu \mathrm{l}$ of extract were mixed with $20 \mu \mathrm{l}$ of treatment buffer and $50 \mu \mathrm{l}$ of this mixture were applied to the well. In gels staining, protocols of Scandalios (1964) for $\alpha$-and $\beta$-EST, Jonathan \& Wendell (1990) for MDH and Heldt (1997) for PRX were used. After staining, gels were washed 2 or 3 times with tap water; fixed in ethanol: $20 \%$ glacial acetic acid $(9: 11 \mathrm{v} / \mathrm{v})$ for $24 \mathrm{hrs}$ and photographed.

\section{Statistical analysis}

Regarding phenolics content, a complete randomize design was used and the obtained data were subjected to analysis of variance (Gomez $\&$ Gomez, 1984) and the treatment means were compared using Duncan's multiple range test and L.S.D. (Duncan, 1955). For protein and isozyme analyses, band weight was estimated by comparing with $1 \mathrm{~kb}$ ladder (Invitrogen, USA) using gel analyzer Ver. 3 program. Differences in bands intensity among profiles of the different samples were not considered. Data generated by SDS-PAGE and isozyme techniques were used to compile a binary matrix for cluster analysis. The presence or absence of each protein and isozyme band was treated as a binary character in preparation of the data matrix (coded 1 and 0 , respectively). Genetic similarity among elicited calli was calculated according to Dice similarity coefficient (Dice, 1945) and used to construct a dendrogram using unweighted pair group method with arithmetic average (UPGMA) by using SPSS-20 program (SPSS, 2011).

\section{Results}

The effect of nine abiotic and biotic elicitors on phenolics content in $R$. damascena callus is shown in Table 1. Except of rose and geranium oils, all other treatments increased the phenolic content in $R$. damascena callus. The highest increment percentages of phenolics content $(152.3,119.3$ and $103.7 \%)$ were recorded under elicitation of citric acid, L-ascorbic acid and casein hydrolysate respectively, without significant differences among them (Fig. 1). On the other hand, yeast extract treatment gave the lowest value of phenolics content increment (3.3\%). It was worth to note that rose and geranium oils decreased phenolics content comparing with control. The reduction was significant for rose oil and insignificant for geranium oil.
TABLE 1. Effect of nine elicitors on total phenolics content of $R$. damascena callus.

\begin{tabular}{|c|c|c|}
\hline Treatments & $\begin{array}{l}\text { "Total phenoics } \\
\text { content }(\mu \mathrm{g} / \mathrm{g})\end{array}$ & $\begin{array}{c}\text { Increase } \\
\%\end{array}$ \\
\hline Control & 2443.7 ef & -- \\
\hline Glycine $(0.5 \mathrm{~g} / \mathrm{L})$ & $4355.6 \mathrm{bcd}$ & 78.2 \\
\hline $\begin{array}{l}\text { Casein hydrolysate } \\
(0.5 \mathrm{~g} / \mathrm{L})\end{array}$ & $4976.7 \mathrm{bc}$ & 103.7 \\
\hline Yeast extract $(0.5 \mathrm{~g} / \mathrm{L})$ & 2523.3 ef & 3.3 \\
\hline $\begin{array}{l}\text { L-Ascorbic acid } \\
(0.5 \mathrm{~g} / \mathrm{L})\end{array}$ & $5358.9 \mathrm{ab}$ & 119.3 \\
\hline Citric acid $(0.5 \mathrm{~g} / \mathrm{L})$ & $6164.4 \mathrm{a}$ & 152.3 \\
\hline Thiamine $(0.5 \mathrm{~g} / \mathrm{L})$ & $3353.6 \mathrm{de}$ & 37.2 \\
\hline Rose oil $(0.8 \mathrm{ml} / \mathrm{L})$ & $213.4 \mathrm{~g}$ & -100.9 \\
\hline Jasmine oil $(0.8 \mathrm{ml} / \mathrm{L})$ & $4052.3 \mathrm{~cd}$ & 65.8 \\
\hline $\begin{array}{l}\text { Geranium oil } \\
(0.8 \mathrm{ml} / \mathrm{L})\end{array}$ & $1863.3 \mathrm{f}$ & -23.8 \\
\hline L.S.D at $5 \%$ & 1010.9 & \\
\hline
\end{tabular}

Figure 2 shows denatured polypeptides of elicited calli of $R$. damascena separated by SDSPAGE. A total number of 14 detectable protein bands (subunits) ranged from 245 to $10.6 \mathrm{kDa}$, were recorded with polymorphism percentage $100 \%$. One unique band was detected at $\mathrm{Mw}$ $69.6 \mathrm{kDa}$ in callus of L-ascorbic acid. On the other hand, five bands with molecular weights 79.4, 68.6, 36.8, 26.3 and 10.6kDa discriminated calli of casine hydrolysate, glycine, yeast extract, citric acid, thiamine and L-ascorbic acid from control. Calli of jasmine, rose and geranium oils revealed same protein banding pattern.

Banding patterns of the four isozyme systems showed considerable variability detecting biochemical aberrations in the tested calli. Occasional discrepancies in the intensity of bands between calli lanes were attributed to the inherent nature of the polyacrylamide gel technique. 12 electrophoretic bands belonging to 10 putative loci; three for $\alpha$-EST, three for $\beta$-EST and two for each of MDH and PRX, were detected in the four zymograms as shown in Fig. 3. Specific alleles; $\alpha$-EST3, $\beta$-EST2 and $\beta$-EST3 were only observed in control. In contrast, elicited calli were discriminated from control by MDH1, MDH2 and PRX2 alleles. The control and seven elicited calli shared four alleles ( $\alpha$-EST1, $\alpha$-EST2, $\beta$-EST1 and PRX1). Calli of geranium and rose oils did not score any band. 


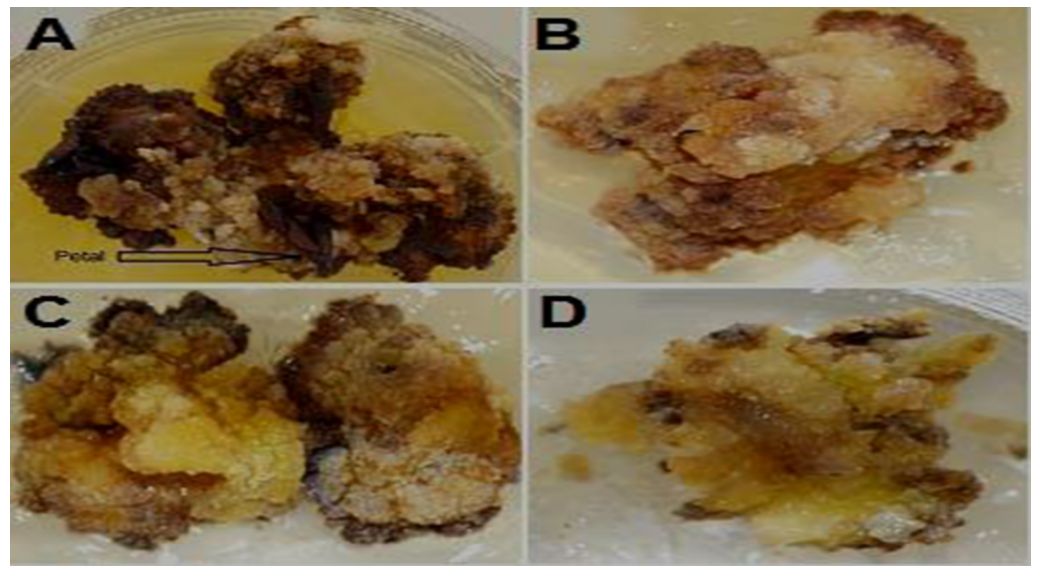

Fig. 1. Callus initiation from petal explants of $R$. damascena as control (A), and under elicitation of citric acid (B), L-ascorbic acid (C) and casein hydrolysate (D).

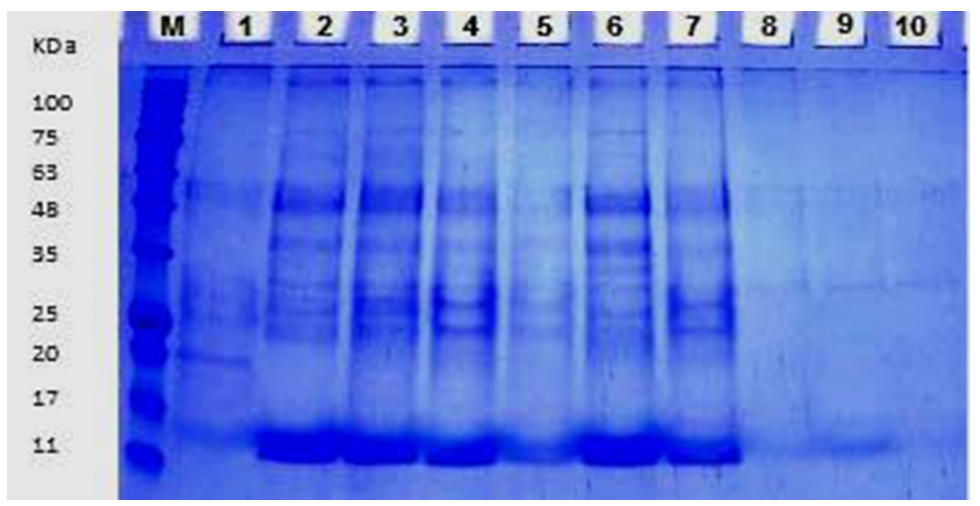

Fig. 2. SDS-PAGE of elicited calli of $R$. damascena. $M=$ Marker, $1=$ Control, $2=B y$ casein hy-drolysate, $3=B y$ yeast extract, $4=$ By citric acid, $5=B y$ thiamine, $6=$ By L-ascorbic acid, $7=B y$ jasmine oil, $8=B y$ geranium oil, $10=$ By rose oil.

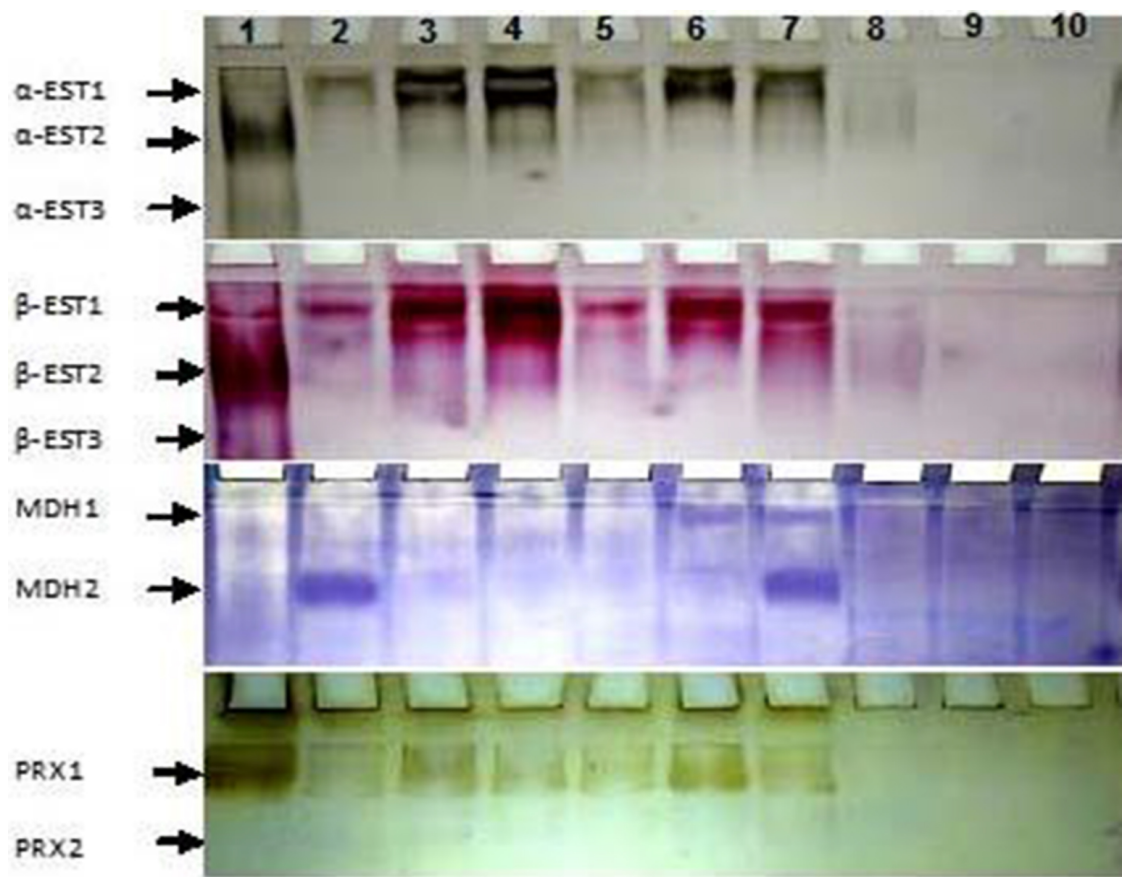

Fig. 3. Zymograms showing isozymes distribution in elicited calli of $R$. damascena. Panel A, $\alpha$-EST, panel B, B-EST, panel C, MDH and panel D, PRX [In all the panels: $1=$ Control, $2=$ By casein hy-drolysate, $3=$ By yeast extract, $4=$ By citric acid, $5=$ By thiamine, $6=\mathrm{By} \mathrm{L}$-ascorbic acid, 7= By jasmine oil, $8=\mathrm{By}$ geranium oil, 10= By rose oil $]$. 
Genetic similarity was calculated from the dice similarity index value for calli of $R$. damascena based on combination of SDS-PAGE and isozymes data (Table 2). The similarity coefficient values ranged from 0.095 to 1.000 , showed a close genetic expression in calli of casine hydrolysate, glycine, yeast extract, citric acid, L-ascorbic acid and control, while least similarity values $(0.211$ and 0.111$)$ were recorded in calli of geranium and rose oils, respectively. The genetic relationships among $R$. damascena calli were analyzed by UPGMA method and presented in a dendrogram (Fig. 4). Calli were grouped into two main clusters (I and II). The first (I) Included calli of control and seven elicitors, whereas, the second (II) Comprised the two calli of geranium and rose oils.

TABLE 2. Dice similarity coefficient of elicited calli of $R$. damascena based on SDS-PAGE and isozyme data.

\begin{tabular}{|c|c|c|c|c|c|c|c|c|c|c|}
\hline & 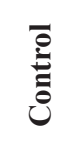 & ن. & 芯 & 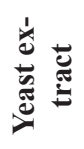 & 胥 & & ن & 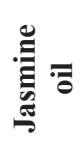 & 音 & 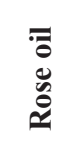 \\
\hline Control & 1.00 & & & & & & & & & \\
\hline Casein hyd. & 0.72 & 1.00 & & & & & & & & \\
\hline Glycine & 0.78 & 0.93 & 1.00 & & & & & & & \\
\hline Yeast extract & 0.78 & 0.93 & 1.00 & 1.00 & & & & & & \\
\hline Citric acid & 0.75 & 0.96 & 0.96 & 0.96 & 1.00 & & & & & \\
\hline Thiamine & 0.70 & 0.83 & 0.88 & 0.88 & 0.85 & 1.00 & & & & \\
\hline L-ascorbic a. & 0.70 & 0.97 & 0.90 & 0.90 & 0.93 & 0.86 & 1.00 & & & \\
\hline Jasmenium oil & 0.58 & 0.60 & 0.60 & 0.60 & 0.63 & 0.51 & 0.58 & 1.00 & & \\
\hline Geranium oil & 0.21 & 0.22 & 0.22 & 0.22 & 0.23 & 0.18 & 0.21 & 0.44 & 1.00 & \\
\hline Rose oil & 0.11 & 0.11 & 0.11 & 0.11 & 0.12 & 0.09 & 0.11 & 0.25 & 0.66 & 1.00 \\
\hline
\end{tabular}

Yeastextract

Citricacid

Casine

Ascorbicacid $>$

Thiamine

Control

Jasmineoil

Geraniumoil

Roseoil

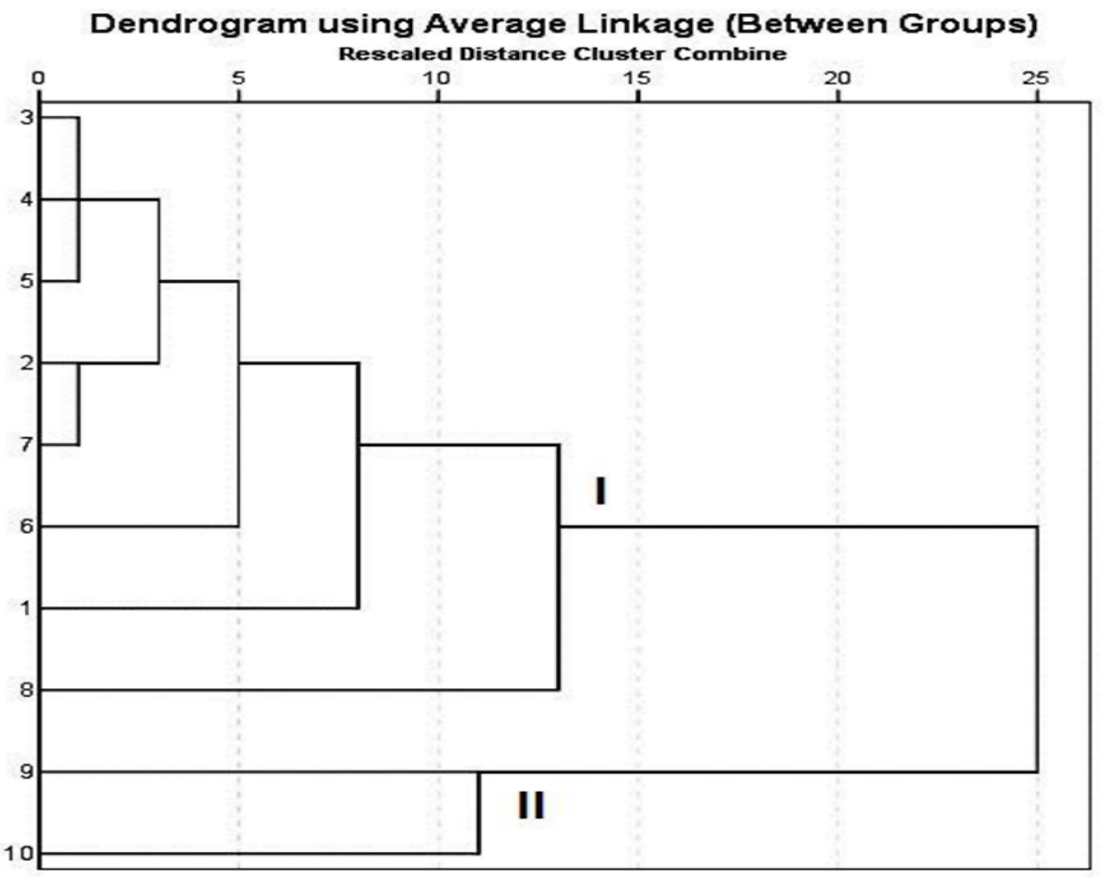

Fig. 4. Phenogram of elicited calli of $R$. damascena based on Dice coefficient of similarity, obtained by UPGMA cluster analysis based on combination of SDS- PAGE and isozyme data. 


\section{Discussion}

Plant tissue culture technology can be established routinely under sterile conditions from explants, such as plant leaves, stems, roots, and meristems for both the ways for establishing callus cell culture and the extraction of secondary metabolites. Several compounds in $R$. damascena petals such as phenolic acids, kaempferol, quercetin, anthocyanins, galactoside and arabinoside have been mentioned by Velioglu \& Mazza (1991). Therefore, in the present study, we reported callus initiated from petal explants of $R$. damascena as a new record using Murashige \& Skoog (1962) (MS) medium. The first report on somatic embryogenesis and plant regeneration from petal explants of $R$. hybrida was achieved by Murali et al. (1996).

The treatment of plant cells with abiotic elicitors as amino acids and vitamins and/or biotic ones as natural products has been a useful strategy to enhance secondary metabolite production in cell cultures (Karuppusamy, 2009). Apparently, results from the present in vitro experiment indicated that citric acid, L- ascorbic acid, casein hydrolysate and glycine increased the phenolics content in callus derived from $R$. damascena. These results are agreed with Erner et al. (1975) who concluded that the stimulating effect of orange juice in promoting recultured orange albedo was a result of its citric acid content as well as the results of Baskaran et al. (2014) who reported that casein hydrolysate gave a sharp increase in total phenolic compounds in Coleonema pulchellum callus tissues. However, results disagreed with Hong et al. (2012) who mentioned that addition of casein hydrolysate did not show any significant increment in accumulation of scopolamine and hyoscyamine in the root cultures of Hyoscyamus niger.

In respect to essential plant oils as biotic elicitors used in this study, it was a matter of interest to notice that the media have rose or geranium oils decreased total phenolics content production compared to control, whereas, phenolics accumulation recorded noticeable increment in callus elicited by jasmine oil. Callus also exposed to yeast extract as biotic elicitor accumulated little amount of phenolics compared to control. For that, yeast extract had not be considered as an elicitor for phenolics production, although, it triggered the production of endogenous jasmonic acid and/ or methyl jasmonate which is considered to be plant signaling molecules that play a key role in plant growth, development and defense responses through influencing the production of secondary metabolites (Sanchez-Sampedro et al., 2005). All elicitors can produce an osmotic pressure and act as stress factors causeing rapid activation for key enzymes in biosynthetic pathway (Gagnon \& Ibrahim, 1997).

To determine the genetic fidelity of a callus derived from in vitro culture, it is important to examine biochemical and molecular aspects. Since enzymes are coded for by genes, any disruption in the coding sequence even at the single base level could force variations in the expression of the enzyme. This study therefore, involved the use of protein and isozyme analyses to scrutinize the genetic expression variation in $R$. damascena callus subjected to different elicitors. SDS-PAGE revealed various protein patterns of expression among elicited calli. Similar result was obtained by Quiroz-Figueroa et al. (2002). The difference in protein profile of an organism could be attributed to the types of tissues and development stages, internal and external conditions (Shepard et al., 2000). Considerable variability was observed in the banding patterns of isozymes showing the presence of biochemical aberrations in tested calli with respect to the control. Results were in accordance with Calderon et al. (1995), Jayasree et al. (1998) and Medina et al. (2004) who reported different isozyme patterns in embryogenic and non-embryogenic calli suggesting that the higher plant cells cultured in vitro showed a genetic instability that was also characteristic of regenerated cells. In this context, the differences in genetic stability are related to differences in genetic make-up, because some components of the plant genome may become unstable during the culture process such as the repetitive DNA sequences (Lee \& Phillips, 1988).

The system by which the regeneration is induced, type of tissue, explant source, media components and the duration of the culture cycle were some of the factors that were involved in inducing variation during in vitro culture (Pierik, 1987). Usually, variability occurred spontaneously and could be a result of temporary changes in cells or tissue during in vitro culture. Temporary changes resulted from epigenetic or physiological effects and were nonheritable and reversible (Kaeppler et al., 2000). Thus, calli of petal explants of $R$. damascena may be subjected to another round of in vitro regeneration to test 
for pre-existing somaclonal variation. Tissues that show pre-existing variation should yield more variability in the first somaclonal generation than in the second generation, and thereafter the variation in the second round can be eliminated or stabilized (Skirvin et al., 1994). Genetic similarity and UPGMA dendrogram distinguished calli into two main clusters; the first cluster grouped the seven elicitors that increased the phenolics content in $R$. damascena callus, while the second included rose and geranium oils that inhibited its production confirming the previous results of elicitation process. Similar results were obtained by $\mathrm{Hu}$ et al. (2011), Mizia et al. (2014) and Machczynska et al. (2015).

\section{Conclusions}

Using petal explants from $R$. damascena, a protocol for callus initiation was developed. Citric acid, L-ascorbic acid and casein hydrolysate as elicitors enhanced the production of total phenolics content. This is a renewable procedure on metabolite production in callus culture of $R$. damascena under the effect of biotic and abiotic elicitation. This elite callus can be used for sustainable production of phenolic compounds which will be helpful in understanding the biosynthetic mechanism of these metabolites under in vitro conditions. Biochemical genetic studies are useful in tissue culture analysis. Protein and isozyme patterns showed qualitative differences among calli of $R$. damascena under study illustrating that genetic expression varied during the elicitation process. Elicited callus variations are important for its use as a tool to produce genetic variability, which will offer great potential for the genetic improvement of $R$. damascena in near future.

\section{References}

Baskaran, P., Moyo, M., Van Staden, J. (2014) In vitro plant regeneration, phenolic compound production and pharmacological activities of Coleonema pulchellum. South African Journal of Botany, 90, 74-79.

Braun, A.C. (1959) A demonstration of the recovery of the crown-gall tumor cell with the use of complex tumors of single-cell origin. Proceedings of the National Academy of Sciences of the United States of America, 45, 932-938.

Calderon, A.A., Zapata, J.M., Ros Barcelo, A. (1995)
Peroxidase isoenzymes as markers of cell dedifferentiation in grapevines (Vitis vinifera). Vitis, 34(4), 207-210.

Crespo, M.E., lvez, J., Cruz, T., Ocete, M.A., Zarzuelo, A. (1999) Anti-inflammatory activity of diosmin and hesperidin in rat colitis induced by TNBS. Planta Medica, 65(7), 651-653.

Dice, L.R. (1945) Measures of the amount of ecological association between species. Ecology, 26, 297-302.

Duncan, D.B. (1955) Multiple rang and multiple F-test. Biometrics, 11, 1-42.

El-Nabarawy, M.A., El-Kafafi, S.H., Hamza, M.A., Omar, M.A. (2015) The effect of some factors on stimulating the growth and production of active substances in Zingiber officinale callus cultures. Annals of Agricultural Sciences, 60 (1), 1-9.

Erner, Y.U., Gold, R.E., Schmdt, E.E. (1975) Partial purification of a growth factor from orange juice which affects citrus tissue culture and its replacement by citric acid. Plant Physiology, 56, 279-282.

Gagnon, H., Ibrahim, R.K. (1997) Effect of various elicitors on the accumulation and secretion of isoflavonoids in white lupin. Phytochemistry, 448, 1463-1467.

Gomez, K.A., Gomez, A.A. (1984) "Statistical Procedures for Agricultural Research". John Wiley $\&$ Sons Inc, New York.

Heldt, W.H. (1997) "Plant Biochemistry and Molecular Biology". Oxford Univ. Press, Oxford.

Hu, J., Qiong, Li, Jing, Li (2011) ISSR analysis of somaclonal variation in callus-derived plants of Amorphophallus Rivieri Durieu. Acta Biologica Cracoviensia. Series Botanica, 53(1), 120-124.

Ivanova, T., Dimitrova, D., Angelov, G., Gussev, Ch., Bosseva, Y., Stoeva, T. (2013) Callus cultures and indirect regeneration of Ruscus hypoglossum in vitro. Bulgarian Journal of Agricultural Science, 19(2), 49-51.

Jayasree, N.B., Devi, P., Vijaya, N. (1998) Somatic embryogenesis and isozymes in rose species $R$. hybrida. Cv. King's ransom. Indian Journal of Genetics, 58(4), 449-454. 
Jonathan, F.W., Wendell, N.F. (1990) Visualization and interpretation of plant allozyme. In: "Allozymes in Plant Biology", D.E. Soltis, P.S. Soltis (Eds.), pp. 5-45. Champan and Hall Press, London, UK.

Hong, M.L.K., Bhatt, A., Ping, N.S., Keng, C.L. (2012) Detection of elicitation effect on Hyoscyamus niger L. root cultures for the root growth and production of tropane alkaloids. Romanian Biotechnological Letters,17(3), 7340-7351.

Kaeppler, S.M., Kaeppler, H.F., Rhee, Y. (2000) Epigenetic aspects of somaclonal variation in plants. Plant Molecular Biology, 43, 179-188.

Karuppusamy, S. (2009) A review on trends in production of secondary metabolites from higher plants by in vitro tissue, organ and cell cultures. Journal of Medicinal Plant Research, 3, 1222-1239.

Kiong, A.L., Mahmood, M., Fodzillan, N.M., Daud, S.K. (2005) Effects of precursor supplementation on the production of triterpenes by Centella asiatica callus culture. Pakistan Journal of Biological Science, 8, 1160-1169.

Laemmli, U. (1970) Cleavage of structural proteins during the assembly of the head of bacteriophage T4. Nature, 227, 680-685.

Larkin, P., Scowcroft, W. (1981) Somaclonal variation a novel source of variability from cell cultures for plant improvement. Theoretical and Applied Genetics, 60, 197-214.

Lee, M., Phillips, R.L. (1988) The chromosomal basis of somaclonal variation. Annual Review of Plant Physiology, 39, 413-437.

Machczynska, J., Zimny, J., Bednarek, P.T. (2015) Tissue culture-induced genetic and epigenetic variation in triticale (3 Triticosecale spp. Wittmack ex A. Camus 1927) regenerants. Plant Molecular Biology, 89, 279-292.

Medina, R., Faloci, M., Marassi, M.A., Mroginski, L.A. (2004) Genetic stability in rice micropropagation. Biocell, 28(1), 13-20.

Mihai, R., Brezeanu, A., Cogalniceanu, G. (2009) Aspects of some elicitors influence on nonmorphogenic callus of Vitis vinifera var. Isabelle. Romanian Biotechnological Letters, 14(4), 45114518.
Miyazawa, M., Okuno, Y., Nakamura, S.I., Kosaka, H. (2000) Antimutagenic activity of flavonoids from Pogostemon cablin. Journal of Agricultural and Food Chemistry, 48(3), 642-647.

Mizia, P., Kwolek, D., Ilnicki, T. (2014) DNA stability contrasts with chromosome variability in Allium fistulosum calli. Acta Biologica Cracoviensia. Series Botanica, 56(1), 66-72.

Murali, S., Sreedhar, D., Lokeswari, T.S. (1996) Regeneration through somatic embryogenesis from petal-derived calli of $R$. hybrida L. cv. Arizona (hybrid tea). Euphytica, 91, 271-275.

Murashige, T., Skoog, F. (1962) A revised medium for rapid growth and bioassays with tobacco tissue cultures. Physiologia Plantarum, 15, 473-497.

Pal, P.K., Singh, R.D. (2013) Understanding cropecology and agronomy of $R$. damascena Mill. for higher productivity. Australian Journal of Crop Science, 7(2), 196-205.

Pierik, R.L.M. (1987) "In vitro Culture of Higher Plants". Kluwer Academic Publishers, Dordrecht.

Quiroz-Figueroa, F., Mendez-Zeel, M., Sanchez-Teyer, F., Rojas-Herrera, Loyola-Vargas V.M. (2002) Differential gene expression in embryogenic and non-embryogenic clusters from cell suspension cultures of Coffea arabica. Journal of Plant Physiology, 159, 1267-1270.

Rao, S.R., Ravishankar, G.A. (2002) Plant cell cultures: Chemical factories of secondary metabolites. Biotechnology Advances, 20, 101-153.

Ren, W., Qiao, Z., Wang, H., Zhu, L., Zhang, L. (2003) Flavonoids: Promising anticancer agents. Medicinal Research Reviews, 23(4), 519-34.

Rodriguez-Sahagun, A., Del Tore-Sanchez, C.L., Gutierrez-Lomeli, M., Castellanos-Hernandez, O.A. (2012) Plant cell and tissue culture as a source of secondary metabolites. In: "Biotechnological Production of Plant Secondary Metabolites", I. Orhan (Eds.), pp. 3-20. Bentham Science Publishers, Sharjah, UAE.

Sanchez-Sampedro, M.A., Fernandez-Tarrago, J., Corchete, P. (2005) Yeast extract and methyl jasmonate-induced silymarin production in cell cultures of Silybum marianum (L.). Gaertn Journal 
of Biotechnology, 22, 60-69.

Scandalios, J.C. (1964) Tissue-specific allozyme variations in maize. The Journal of Heredity, 55, 281-285.

Shepard, J.L., Olsson, B., Tendengren, M., Bradley, B.P. (2000) Protein expression signatures identified in Mytilus edulis exposed to PCBs: Copper and salinity stress. Marine Environmental Research, 50, 337-340.

Singleton, V.L., Rossi, J.A. (1965) Colorimetry of total phenolics with phosphomolybdic-phosphotungstic acid reagents. American Journal of Enology and Viticulture, 16, 144-158.

Skirvin, R.M., McPheeters, K.D., Norton, M. (1994) Sources and frequency of somaclonal variation. Hort. Science, 29, 1232-1237.
SPSS (2011) SPSS Statistics for Windows, ver 20. SPSS Inc, Chicago.

Stegemann, H., Afify, A.M.R., Hussein, K.R.F. (1987) Identification of date (Phoenix dactylifera L.) cultivars by protein patterns. Phytochemistry, 26, 149-153.

Thevenot, E.C., Mass, O., Jouevne, T., Mauro, M.C., Boulay, M., Deloire, A., Guern, J. (1992) Extracellular protein patterns of grapevine cell suspensions in embryogenic and non-embryogenic situations. Plant Science, 86, 137-145.

Velioglu, Y.S., Mazza, G. (1991) Characterization of flavonoids in petals of $R$. damascena by HPLC and spectral analysis. Journal of Agricultural and Food Chemistry, 39, 463-467.

\footnotetext{
محفزات تحسين محتوى الفينولات واختلاف التعبير الجيني المصاحب فى كالوس بتلات

الورد الامشقي

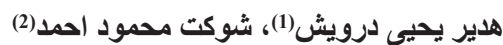

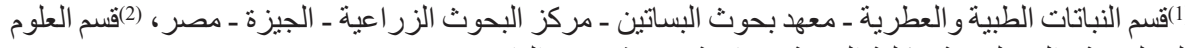

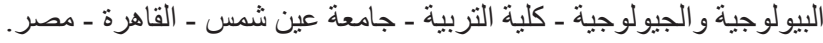

انطلاقا من الأهمية المنز ايدة لإستخدام نبات الورد في انتاج المنتجات الثانوية مثل الزيوت الإنات الطبيعية و المركبات

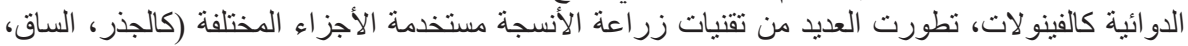

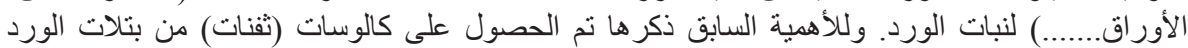

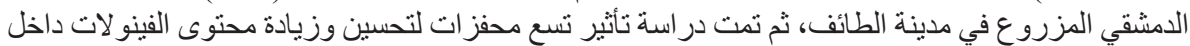

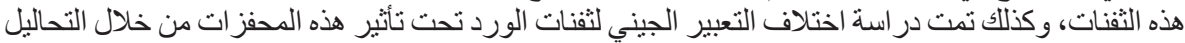

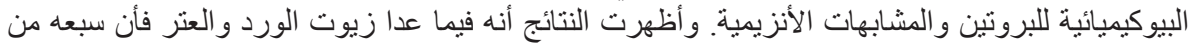

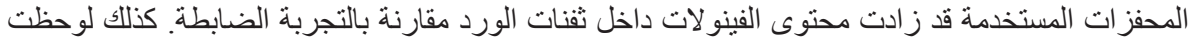

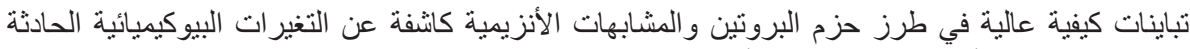

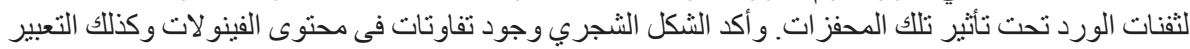

الجيني لتفنات الورد.
} 